\title{
Human Capital and Risk-Bearing
}

\author{
by Jacques $\mathrm{H}$. Drèze *
}

\section{Forms of risk-sharing}

The economic theory of decision-making under uncertainty and risk-bearing rests on the assumption that individual agents behave consistently. If preferences do not depend upon the state of nature and if there exist opportunities for gambling at fair odds (say, on the stock-market, or through private bets), then consistent behaviour implies aversion, or at least neutrality, towards economic risks - cfr Drèze [1971]. Casual empiricism confirms that risk-aversion is indeed the rule: Most individuals seem eager to shed their risks, even at unfair odds.

These risks take many forms, and affect an individual's health, his wealth, his liability, etc. Risk-shedding is achieved mainly through diversification, exchange or insurance. Each one of these three devices is limited in scope.

Diversification consists in splitting a risk into components with limited stochastic dependence, thereby reducing the total variance. Asset portfolios provide an example. But diversification entails costs of information and transactions. And an element of stochastic dependence is always present on the level of general economic activity: Collective risks (as opposed to individual risks) cannot be eliminated through diversification ${ }^{1}$.

Exchange sometimes enables strongly risk-averse individuals to sell their risks to other agents who are more tolerant or endowed with complementary risks. Future markets enable buyers and sellers to shed price uncertainties (but not quantity uncertainties). Equity financing is a way of selling business risks. But exchange must take place before the relevant information becomes available (once a lottery is drawn, there is no market any more for its tickets). Consequently, information could be harmful! When I drew attention to this apparent paradox in Economie Appliquée some twenty years ago, I was not fully aware of its significance, which has been brought out by Hirshleifer and recently discussed by Arrow in the first annual Lecture of the Geneva Association - cfr Drèze [1960], Hirshleifer [1971] and Arrow [1978]. As noted by Arrow, there may arise conflicts between efficiency in production and efficiency in risk-sharing. These conflicts are sometimes resolved by exchanging risks before pooling the relevant information, but producing afterwards.

* Director of the Center for Operations Research \& Econometrics (CORE) at the Université Catholique de Louvain.

1 On this notion, see Allais [1953]. I have given an implicit definition: Risks are "individual" or "collective" according as they can, or cannot, be eliminated through diversification. 
Mutual insurance is a form of diversification. Commercial insurance involves an exchange followed by diversification. (The policy holder sells his risks to a company which resorts to diversification in a systematic and scientific way, through reinsurance if necessary.) But here again there are limitations. Transaction costs may absorb up to $50 \%$ of the premium for small risks. Diversification typically relies on actuarial experience ${ }^{2}$. And insurance is subject to the paramount limitations of moral hazard and adverse selection. When the probabilities of a casualty are to some extent influenced by the policy holder, or are better known to him than to the company, the scope for insurance is reduced. This explains why insurance against celibacy or divorce is so uncommon.

In the words of Arrow [1965]: "The insurance policy might itself change incentives and therefore the probabilities upon which the insurance company has relied. Thus, a fire insurance policy for more than the value of the premises might be an inducement to arson or at least to carelessness." Borch [1979] uses game theory to measure the cost of moral hazard for policy holders through higher premiums.

\section{Risks affecting human capital and opportunities for sharing these risks}

This short overview is useful for appraising the distinction between risk-sharing opportunities for physical capital on the one hand and for human capital on the other. The concept of "human capital" entered economics some fifteen years ago, to denote the present value of a stream of labour income - cfr Becker [1964]. Because future labour income are uncertain, human capital bears risks, which fall under three headings. Some risks are physical - death accidents, illness. Insurance coverage of these risks is well developed, at the individual, group and social level. Other risks are economic; they result from the endogenous and exogenous uncertainties affecting labour income. The endogenous uncertainties concern an individual's proficiency at work: Qualifications, creativity, drive, sociability,... The exogenous uncertainties concern the demand for the labour services offered by an individual : High demand at times of full employment, but low demand at times of underemployment; a demand which assigns to a particular type of labour a higher or lower value, depending upon business conditions and industrial structures.

Risks surrounding individual abilities are particularly hard to shed. Diversification is ruled out, short of a dual personality. Exchange has disappeared, together with slavery. As for insurance, it is particularly curtailed, in this area, by the problems of subjective assessment, moral hazard and adverse selection. A singer can easily take out insurance against throat cancer, but not against hostile audiences or new " musical " styles. Insurance companies do not protect students against insufficient grades, employees against lack of promotion or authors against stubborn editors.

In the case of the self-employed, the distinction between endogenous and exogenous economic uncertainties is not always clear-cut. When a supermarket drives the local

2 Still, Borch [1977] gives a racy account of the contract whereby Lloyds of London insured the Cutty Sark whisky company against capture of the monster in Loch Ness, for a premium of $2.5 \%$. 
grocery store out of business, is that evidence of carelessness or bad luck ? Perhaps the presumption of carelessness would be enhanced if the grocer carried insurance against business failure ? And one would like to know what provisions, if any, the insurance contract contained regarding price policy, advertising, service quality, etc.

A self-employed person has no effective way of shedding his professional risks other than through salaried employment - possibly in trades where income variability is largely unrelated to individual productivity (like in the case of unskilled workers or tenured professors). The relationships between risk-aversion and income distribution have not yet been fully charted. Shortly before the revival of the theory of decision-making under uncertainty, Friedman and Kuznets [1945] expressed some surprise at their discovery of a positive rank correlation between mean and variance of income from independent professional practice. They sought an explanation for this phenomenon on the demand side, but could find none. A few years later, Friedman [1953] presented in Paris his explanation of the dispersion in personal incomes through attitudes towards risks.

My main interest here centers on risks arising from the demand for labour. These may consist in uncertainty about wage levels, especially in the long run ; or in uncertainty about labour demand at given wages, especially in the short run. This last phenomenon, namely unemployment risk, will be my main - and timely - concern. A wage- or salary-earner may be uncertain about short run labour demand at three levels, namely: The firm, the trade or sector, and the economy as a whole. Risks arising at firm level are largely diversifiable, whereas those arising at an economy-wide level are definitely "collective". In between, the two types of risks are mixed in varied proportions. When the labour demand of a particular firm changes, there may be some doubt, at least temporarily, as to whether the change is specific to the firm, or is of a broader nature. This obvious remark illustrates a recurrent theme in the recent literature on anticipations, namely the difficulty in distinguishing the individual and the collective components of observed disturbances (for instance, of distinguishing changes in relative prices from changes in the general price level); as we shall see below, this difficulty is relevant for the policing of labour contracts - cfr Fisher [1977].

Here again, the scope for diversification is almost nil. A given person seldom works for several firms, or in several trades, simultaneously. And the risks arising from general business conditions cannot be diversified, by definition ${ }^{3}$. As for exchange, it takes the form of labour contracts, with more or less elaborate guarantees for the workers (concerning wage rates, hours, employment stability, dismissal notice, severance pay, ...). I will discuss this topic at some length below. I would like to state, however, that successful execution of the contract is predicated upon solvency of the firm. Bankruptcy insurance is hampered again by the problems of moral hazard and adverse selection already mentioned in the case of the self-employed. From the workers' viewpoint, insurance typically takes the form of unemployment compensation, in a social security framework. The provisions (amount, duration, ...) are thus fixed by collective rules instead of privately agreed contracts.

3 Let us note, for further reference, that uncertainty about rates of monetary inflation, without any real counterpart, could be covered by escalator clauses (indexing). 


\section{Risk-tolerance of firms and workers}

There exists a marked difference between the risk-sharing opportunities applicable to human capital, which are narrowly limited; and those applicable to physical capital, which are quite extensive. Financial intermediation has made an important contribution, through the creation of negotiable securities. Unlike human capital, financial assets are divisible and free of transportation costs. This opens up opportunities for diversification which are substantial (although still imperfect). In particular, financial diversification operates across firms, sectors and even nations.

As noted by James Meade [1972]: "While property owners can spread their risks by putting small bits of their property into a large number of concerns, a worker cannot put small bits of his effort into a large number of different jobs. This presumably is a main reason why we find risk-bearing capital hiring labour rather than risk-bearing labour hiring capital". To be sure, labour management does not rule out equity financing - cfr Drèze [1976 a]. But Meade's point is well taken, and applies also to such forms of compensation as gratuities or sharecropping - cfr Stiglitz [1974].

For these reasons, I believe that risk-tolerance is greater :

- for owners of non-human capital than for owners of human capital ;

- for corporations than for the self-employed ;

- for firms than for workers.

It would be worthwhile to test the first of these propositions by measuring riskaversion, as defined by Arrow [1965] and Pratt [1964], first on the basis of stockmarket valuations; and secondly on the basis of insurance contracts subscribed by broad groups of individuals (like all automobile owners, or home owners). The latter measurement could be carried out, from the files of insurance companies, relying upon the theory of optimal insurance discussed below.

The second proposition is illustrated by the behaviour of the self-employed who pay a high price to reduce their professional risks; I am referring in particular to farmers, who resort to technically inefficient diversification of production activities as a substitute for assets diversification.

The third proposition plays an important role in what follows, and deserves a word of explanation. According to what criteria do business firms make decisions under uncertainty ? This is a debated issue, about which opinions differ. Some work rests on the assumption that firms are risk-neutral ${ }^{4}$. The implicit rationale for this assumption is that portfolio diversification by shareholders eliminates the individual risks specific to a firm. But collective risks are still there; they are measured, say, by the covariance between the profits of a given firm and national income. Furthermore, many business firms insure individual risks (fire, machine breakdowns, theft, ...), thereby revealing their risk-aversion. This may be explained, at least in part, by the linkage

4 See for instance, Drèze [1976 b] and the references there to Drèze-Gabszewicz [1967], Sheshinski-Drèze [1977] or Tisdell [1968]. Malinvaud [1972] shows that efficiency requires firms to be neutral towards individual risks. 
of risks. Thus a liquidity crisis may call for costly emergency measures (selling inventories at discount prices, curtailing turnover, using expensive credit margins, ...). In the more acute cases of bankruptcy, fixed assets are apt to be sold on disastrous terms. Accordingly, business firms are not entirely risk-neutral. But many risks which are serious for individuals are innocuous for firms - because stock ownership permits portfolio diversification by owners of non-human capital, who have an opportunity to invest their wealth in low-risk assets.

\section{Sharing income-risks : An example}

In order to assess the implications of the difference in risk-aversion between workers and firms, let us consider the example of the steel industry in Luxembourg. Everywhere in Europe - and Luxembourg is no exception - the steel industry faces sizeable demand fluctuations, which result in commensurate fluctuations in the degree of capacity utilization. There are in Luxembourg a number of steel workers who have few alternative employment opportunities in the short run. If their wages were set each year (month) at a level equating labour supply to industry demand, these wages would fluctuate with demand. At this time (March 1979), they would have to be low enough for steel workers to be indifferent to working or staying home; at which point excess supply disappears by definition! On the other hand, at times of strong demand and high prices for steel products, wages would also be very high. When will such a situation prevail again? This question is surrounded by considerable uncertainty.

The arrangement which I have just described would of course entail serious drawbacks for steel workers, especially if they are young and have no savings. How could this arrangement be improved ? A first approach - which provided the motivation for my work on equilibrium with price rigidities [1975] - would consist in seeking improvement through mutual insurance. Workers from steel works, hotels and vineyards could pool and share their incomes, fully or partly; this form of diversification would reduce individual risks. This approach must however fulfil certain conditions, in order to be successful. Suppose that wages of steel workers become low enough to make them indifferent to working or staying home. In the framework of mutual insurance, this means "working and contributing one's earnings to the mutual fund" or "staying home and nevertheless receiving benefits from the mutual fund" - a perfect example of moral hazard! In order to set things straight, the group must agree about a wage rate below which its members may refuse to work while remaining eligible for their share of the pool. This brings in a form of downward wage rigidities, and in particular a minimum wage.

Actually, the mutual insurance approach retains the drawback of restricting diversification to owners of human capital. Why not extend the mutual arrangement to owners of physical capital ? Since they are more risk-tolerant, they could buy a share of the risks borne by workers, for a suitable premium. This looks good - but perhaps a bit difficult to organize. Indeed, one must somehow control whether each member of the group contributes the agreed-upon share of his earnings. (A fixed contribution would contradict the very idea of mutual insurance.) This calls for checking the amount of earnings with the employer. In the steel industry, employers are joint stock companies. Why not invite the steel company to join the mutual 
insurance group, both as a seller of insurance and as a controller (of earnings) ? So far so good - but then, it may no longer be necessary for the steel company to pay its workers, collect a share of their earnings as insurance premium, and finally pay out an insurance benefit. It would seem easier, and more attractive from the tax angle (in Luxembourg) to immediately register the final amount as a wage. This brings in rigid wages, independent of business conditions, paid out directly by the employer.

There remains a problem, however. Suppose again that the marginal value product of labour is such that workers would rather go hunting and eating quail than working and earning this marginal product. Under flexible wages, they would be voluntarily unemployed. Under rigid wages, they prefer to work. So the employer will use authority and lay them off. Rigid wages and involuntary unemployment have thus replaced flexible wages and voluntary unemployment - without any change in the real situations (employment level), but with a transfer of risks from the workers to the firms.

\section{Implicit labour contracts and contractual equilibria}

We have just rediscovered the concept of "implicit labour contract", introduced five years ago by Azariadis [1975], Baily [1974] and Gordon [1973], and soon followed by Barro [1977], Grossman [1977] and others. The idea is simple. Suppose that a firm faces a demand (price) subject to random fluctuations. At a given level of labour input, the marginal value product of labour will also be random. Should a worker receive a wage equal to the marginal value product of his labour, the variance of earnings would entail for him a loss of utility. The firm may then offer him a fixed wage, inferior to his expected marginal value product, but more attractive than the random wage, both for the risk-averse worker and for the risk-tolerant firm. Both parties have incentives to sign a contract specifying a fixed wage, unaffected by demand fluctuations. It is an employment contract, coupled with an implicit insurance contract 5 . The worker earns a wage equal to the marginal value product of his labour, plus an insurance benefit in case of adverse business conditions, but minus an insurance premium in case of favorable business conditions. The insurance contract is underwritten by the firm itself, and not by an insurance company, because the firm has immediate access to the information required in order to monitor the contract (the marginal value product of labour) ; the insurance company would be confronted with a moral hazard problem.

In the simplest model, initially considered by Azariadis and Baily, the firms are risk-neutral ${ }^{6}$ and the length of the working week is fixed. When demand (price) is very low, the value of the output of the last (marginal) worker is inferior to his disutility of working. The implicit contract calls then for laying off temporarily a number of workers just sufficient to raise the value of the output of the marginal worker back to

5 For some authors, like Grossman [1978 a], the term "implicit" is due to the illegality of involuntary servitude - a common law principle dear to married men.

6 When firms are somewhat risk-averse, wages should undergo slight variations which can be ignored in the presence of transaction costs. 
parity with the disutility of work; this adjustment is mutually advantageous 7 . This "implicit contracts" model leads to stability of the real income of employed workers, but to instability of employment. Stability of real, as opposed to nominal income, calls for tying wages to the consumer price index.

Extensive reliance upon this type of contract could, according to some of the afore-mentioned authors, explain why wages do not reflect the cyclical fluctuations of the marginal value product of labour, i.e. why wages are rigid in the short run. In this way, a phenomenon which plays an important role in Keynesian macroeconomics would receive rational microeconomic foundations. (Unlike Keynes however, our authors do not assume that employment is at all times such as to equate the rigid wage, to the marginal value product of labour.)

The most sophisticated version of this model is due to Bengt Holmström [1979], in a general equilibrium framework with two periods and uncertainty about the state of nature in the second period. A "contractual equilibrium" includes labour contracts specifying a first period wage and, for each state of nature in the second period, a wage and a rate (probability) of unemployment. Holmström assumes that competition on a homogeneous labour market in the first period brings about a unique wage (for all workers and all firms). In the second period, once the state of nature becomes known, two situations may arise. If labour demand is high, wages go up and full employment is obtained at a unique wage rate. If labour demand is low, wages are downward rigid and some of the workers are laid off. In equilibrium, expectations are rational, and there exist no alternative wage contracts simultaneously more appealing to workers and firms. The fact that wages are rigid downwards but not upwards follows from the assumption that workers could break their first period contract if another firm offered them a higher wage (illegality of involuntary servitude).

Holmström proves existence of a "contractual equilibrium" for an economy with a single commodity, an arbitrary number of risk-neutral firms with convex production sets, and a continuum of identical workers with concave preferences.

He then considers a sequence of competitive (Walrasian) spot equilibria - without futures markets or insurance markets. He shows that wages and employment in the second period are never higher at competitive spot equilibria than at contractual equilibria, whereas the expected utility of workers is higher or at least equally high at contractual equilibria. The first result follows from the fact that efficient labour contracts keep workers employed so long as their marginal product is at least high enough to compensate them for the disutility of working. The second result is due to the fact that downwards wage rigidity reduces the variance of labour incomes, in comparison with the sequence of competitive spot equilibria. In order to do better still, one should introduce insurance markets, or a working week of variable length. With reference to this last point, one could imagine that lay-offs would affect all the workers of a given firm symmetrically as they would take them in turns. This is equivalent to variable hours.

7 Indeed, the savings accruing to the firm through temporary lay offs permit an increase in the fixed wage rate. 


\section{Unemployment compensation and seniority rights}

These results demonstrate the relevance of the concept of "implicit labour contract" and of risk-bearing for a better understanding of some aspects of labour markets. I will now introduce some variations on this theme, then turn to a normative discussion of risk-sharing through labour contracts.

An element duly stressed in the literature has not thus far been mentioned, namely unemployment compensation under social security provisions. Let us first investigate their rationale, in the general framework introduced so far $^{8}$. I think that this rationale rests at least in part with the residual risk-aversion of business firms and with their bankruptcy risks. The first point explains why firms, especially small firms, find it more advantageous to participate in a national scheme than to guarantee themselves a replacement income to their temporarily laid off workers. The second point explains why workers find it more advantageous to receive such replacement income from a national agency than from possibly insolvent firms. (Note furthermore that an outside agency must take over when a worker is permanently dismissed. The least able workers are the main beneficiaries of unemployment compensation.)

Now, social unemployment insurance has two implications which are important for our discussion. First, unemployment compensation must be added to the disutility of labour in defining the opportunity cost of employment. It is well known that unemployment benefits do influence the supply of labour, because some persons find it more appealing to draw these benefits than to earn more through work. The law does not always succeed in denying them unemployment benefits. But these benefits also influence the demand for labour by firms. We saw earlier that efficient implicit contracts keep employment at a level where the product of a marginal worker is at least equal to the disutility of working. Actually, this product must be at least equal to the sum of the disutility of labour and the unemployment benefits.

An implicit contract which is efficient from the viewpoint of a firm and its workers treats unemployment compensation as an external benefit, which is advantageously internalized by temporary lay-offs at times of slack demand. This result holds so long as the marginal cost of unemployment benefits is not borne by the firm and its workers. Such is generally the case in Europe; I understand that it is also the case for most American firms, in spite of partial adjustment of social security contributions to a firm's past record regarding employment stability ${ }^{9}$. Accordingly, Baily [1977], Feldstein [1976] and Grossman [1978] feel that unemployment compensation schemes have a negative impact on employment stability, an impact which is conducive to inefficiency. Unemployment insurance is thus plagued by moral hazard, both because it reduces effective labour supply and because it adds to instability of labour demand.

A second implication of unemployment compensation schemes is their negative impact on incentives to reduce temporarily the length of the working week at times of excess labour supply. Suppose that a firm wishes to reduce by $10 \%$ the total number

8 Curiously, this point is not treated in the papers dealing with implications of social unemployment insurance - cfr Baily [1977], Feldstein [1976] and Grossman [1978 b].

9 Cfr Feldstein [1976, fn 25] ; Baily [1977, p. 1058]. 
of man hours worked by its employees. If it reduces by $10 \%$ the length of the working week (say from 40 to 36 hours), no unemployment compensation is involved. If instead $10 \%$ of the workers are laid off, they will collect unemployment compensation ; the firm and its employees should find it advantageous to internalize these external benefits. This remark may help to explain the relative rigidity of working hours through spells of unemployment ${ }^{10}$.

Another phenomenon, emphasized by Grossman [1977, 1978 a] and Holmström [1979], is the common practice of seniority rights. They may take the form of higher wages, or higher employment stability ${ }^{11}$ for the workers with higher seniority within the firm.

Seniority rights may be justified on productivity grounds, since more senior workers have acquired more experience on the job. The theory of implicit contracts provides an additional explanation. If a worker is employed, sometimes for a wage inflated by an insurance benefit and sometimes for a wage deflated by an insurance premium, it is important that a proper balance should exist between both types of periods. But in periods of high labour demand, workers employed under a previous contract have an incentive to change firm, thereby dodging the implicitly agreed upon premium (moral hazard!) to start afresh in another firm at a higher wage. Seniority rights combat this incentive and promote workers' stability, without violating the illegality of involuntary servitude.

As for firms, their incentives to honour implicit contracts are tvpically sought in the desire to acquire a reputation of reliability, which induces stable workers to contract with them. Note however that this motivation disappears when a firm closes down, since any goodwill acquired in this way disappears with the firm. It should not surprise us that workers dismissed by such firms react as victims defrauded of an implicit right to employment stability - i.e. as the party wronged through violation of the implicit contract.

\section{Empirical relevance of the implicit contracts theory}

The main points made so far are listed in the left side of the table in Appendix, which aims at bringing out their interrelations. The right side concerns the normative analysis, to which I shall soon turn. Prior to that however, I would like to comment briefly upon the realism and empirical relevance of the implicit contracts theory.

I have been concerned with implications of the absence, in our economies, of adequate opportunities for spreading or insuring the economic risks of human capital. Needless to say, the explanations contributed by the theory of risk-bearing have a partial character and do not exhaust the topics under discussion. The theory of implicit labour contracts should not lead anyone to believe that the massive unemployment observed today in several countries is "implicitly voluntary". Neither should one neglect the role of adjustment costs, stressed for instance by Oi [1962], or of the

10 Feldstein [1976, p. 938] refers to union contracts requiring that firms lay-off workers instead of reducing average hours per week.

11 Feldstein [1976, p. 938] refers also to union contracts with inverted seniority provisions, whereby the more senior workers have the option of being laid off first instead of last. 
increasing returns to working time, stressed by Feldstein [1976], in explaining the cyclical rigidity of hours worked.

The first question to be raised about the empirical relevance of the theory concerns the extent to which labour contracts actually include an (implicit) insurance policy. This question is not easy to answer, because the provisions of the insurance policy are clearly defined only under the extreme (and unrealistic) assumption that firms are risk-neutral, in which case labour incomes should be non-stochastic - also for temporarily laid-off workers, which is seldom the case. In general, some variability in labour incomes remains appropriate, and a quantitative yard-stick should be developed against which observed variability could be gauged. Separate measurements of risk-aversion by firms and workers, as already advocated in section 3 , would here be called for.

Casual empiricism reveals substantial variations as between countries, sectors, firms and types of labour. Thus, escalator clauses protecting real income are more extensive in some countries than others - see Azariadis [1978]. Income stability is much greater in some industrial sectors (automobile) than others (textiles). Large firms seem to offer more guarantees than small firms. Most conspicuous perhaps is the difference in status between blue collar wage-earners, and white collar salary-earners who are seldom laid off temporarily. To the best of my knowledge, a systematic analysis of these differences is still lacking; it should include other elements beside risk-bearing - as in the theories of labour market segmentation; see Cain [1976]. Such an analysis is a prerequisite to proper assessment of the empirical relevance of the implicit contracts theory.

A second empirical question to be raised about this theory concerns the extent to which implicit labour contracts lead to privately efficient employment policies - i.e. to policies whereby the marginal value product of labour is always equal to its private opportunity cost. Some authors, in particular Barro [1977] and Grossman [1978 b], defend that assumption. I would tend to side with S. Fischer [1977], who questions it. Fischer's reservations derive from moral hazard. On the one hand, the disutility of working is hardly observable and firms would be reluctant to insure workers against fluctuations in labour demand. My own reservations are of a different nature. I regard implicit contracts as bearing on commodities with multiple characteristics, where the characteristics (state distributions of wages and rates of unemployment) are not given but must be chosen by the firms. And we know that competitive mechanisms can correctly guide the decisions about quantities for a given set of commodities, but not the choice of characteristics for these commodities. The set of feasible combinations of quantities and qualities is not convex, and the presumption of efficiency is therefore unwarranted ${ }^{12}$.

\section{Normative analysis : Productive efficiency and optimal insurance}

Turning to the normative analysis, I must point out that the existing literature consists of partial equilibrium models with many periods - as in the work of Baily [1974] or Azariadis [1975] - and general equilibrium models with two periods - as

12 The non-convexities result from simultaneous modifications in the contract and the personnel of a given firm - see Drèze and Hagen [1978]; or in the contract and the equipment of that firm - see de Kerchove [1976]. 
in the work of Holmström [1979]. Yet the time dimension is just as important, for our problem, as general interdependance. Clearly, the wage of a shop attendant does not vary with the sales volume from hour to hour or day to day. What we are concerned with is the cyclical pattern of wages and employment. Equally clearly, the attendant will be dismissed if the shop closes down. A difficult issue is to know when closing down the shop is justified, due account being taken of the labour contract. Normative analysis of this issue should rest on general equilibrium models with several periods, uncertainty and incomplete insurance markets. Such models have not yet been treated in the literature, to the best of my knowledge. I will accordingly base my normative discussion on two theoretical contributions of more limited scope : The theory of productive efficiency under certainty; and the theory of optimal insurance for given risks.

The theory of Pareto-efficiency requires that labour inputs be so allocated that (i) the marginal value product of labour be the same in all its uses, i.e. in all firms, and (ii) the marginal value product of labour be just sufficient to compensate for the marginal disutility of working.

The first equality requires mobility of workers between firms, so as to continuously reorient labour towards the most productive activities. Seniority rights hamper mobility and may discourage workers from changing firms. Indeed a worker may be reluctant to give up his seniority rights, without full immediate compensation, even though his future productivity may be superior elsewhere.

The second equality is violated when the implicit contract is ineffective, so that firms equate the marginal value product of labour to a rigid wage; and again when the implicit contract is privately efficient, with firms equating the marginal value product of labour to its opportunity cost, consisting of disutility of work plus unemployment compensation. The second equality may also require cyclical fluctuations in hours worked, reflecting cyclical fluctuations in demand. This point is quite obvious for small countries, who cannot control the cyclical fluctuations in world demand. When the world demand for Belgian labour diminishes, whereas the Belgian labour supply is unchanged, labour inputs in Belgium should go down. If the rationing of supply is not achieved through price adjustments (lower wages), because fluctuations in real income are costly for risk-averse workers, then labour supply must be subjected to quantity rationing. But quantity rationing through shorter hours is socially more efficient than quantity rationing through unemployment.

I will come back in my concluding section to some means whereby one could hopefully reduce the gap between our practice and these norms of Paretian efficiency. Prior to that, I still want to quote the two main results from optimal insurance theory, proved respectively by Borch [1960] and Arrow [1970].

Borch has demonstrated the following proposition 13: "If the insured and the insurer are both risk-averters and there are no transaction costs, then any non-trivial Pareto-optimal policy stipulates benefits which increase with the loss, but in such a way that an increase in the loss never be fully insured."

13 I am quoting here the formulation in Arrow [1970, p. 216]. 
This proposition, applied to the collective risks of general business conditions, would require universal sharing of these risks, with no one fully insulated. Yet downward rigid real wages insulate employed workers from the collective risks of insufficient world demand, deterioration in terms of trade, etc. A similar conclusion is reached by Azariadis [1978] in his paper on escalator clauses. In the case of collective risks ("real" shocks), only partial indexing of money wages is justified.

A different conclusion holds for individual risks, which disappear at the collective level through compensation or diversification. Azariadis recommends full indexing of money wages against purely monetary disturbances. This is consistent with the theorem of Arrow [1970 b] on optimal insurance of individual risks : "If an insurance company is willing to offer any insurance policy against loss desired by the buyer at a premium which depends only on the policy's actuarial value, then the policy chosen by a risk-averting buyer will take the form of 100 per cent coverage above a deductible minimum."

The reasoning in the proof of this proposition applies to the case of income risks as well. In the case of individual risks, insurance at a premium depending only upon actuarial value makes sense. Full coverage above a deductible minimum becomes full downwards rigidity of real incomes not exceeding a given level (like in the case of full indexation up to a given ceiling). The level of income up to which full downwards rigidity applies plays the same role here as the level of wealth net of deductible losses in Arrow's formulation.

\section{Suggestions for possible Improvements}

In the light of these remarks, I wish to suggest some avenues along which improvements to our institutions could be sought. All my suggestions aim at alleviating the rigidities of these institutions.

(a) Income flexibility. The theory of optimal insurance suggests that individual incomes should be independent of individual risks, but not of collective risks. This calls for indexing wages and salaries on national income at current prices, rather than on consumer prices. Thus, any monetary disturbance without real effects would automatically be offset by proportional adjustments in wages and salaries. On the other hand, in a recession, the fall in real national income would be shared by all, as required by Borch's theorem.

This suggestion is conceptually simple, yet difficult to implement. Indeed, arithmetic indexation of all earnings on national income would leave no room for adjustments in income shares. In order to retain some flexibility, one could for instance subtract from the rate of change of national income at current prices, the rate of change in productivity, whose contribution could be redistributed freely. Alternatively, one could index earnings up to a ceiling amount, in order to leave room for some redistribution of personal incomes. Arrow's theorem allows for such a ceiling, which plays the same role as a deductible minimum. Failure to index tax brackets has roughly similar effects and might find here a rationale which deserves further study.

Another difficulty is that official data on national income are published with considerable delay - one year or more. In contrast, the consumer price index admits rapid measurement. My colleague A. Steinherr [1978] has suggested tying wages and 
salaries to a price index of value added - an index which aims at tracking the ratio of nominal to real national income. This is an interesting suggestion, which meets the objective as well as the objections just mentioned. Another possibility would be to use the rate of unemployment in order to curb escalator clauses during recessions. This rate has the merit of being measured without lags and of being generally familiar. But the best way of using it for our purposes remains to be defined.

(b) Flexibility of hours worked. I have indicated above why some flexibility in hours per week might be desirable, to absorb cyclical fluctuations in demand. I have also indicated how standard unemployment compensation schemes impose a penalty on this way of rationing labour supply. The penalty would disappear if unemployment benefits were proportional to the number of hours of involuntary unemployment (the standard working week minus hours effectively worked). But this suggestion may have its drawback, because workers would feel motivated to oppose reduction in the standard working week, even when such reduction are required for full employment 14 .

(c) Employment stability. I have also indicated how unemployment compensation, because it enters into the private opportunity cost of labour, tends to destabilize employment (lay-offs internalize an external benefit). On the other hand, when the marginal cost of unemployment compensation is borne by the firm, the destabilizing effect disappears. This is the reason why some authors, like Feldstein [1976], have suggested that contributions to unemployment compensation schemes should be geared to the past record of firms. A record of employment stability would lead to low contributions, and conversely. This principle has found little application in Europe, where it should be studied carefully.

(d) Labour mobility. Among the sources of conflict between productive efficiency and risk-sharing, I have mentioned seniority rights. They help in monitoring implicit labour contracts, but they discourage the mobility of workers between firms. Perhaps these rights could become transferable, whenever those concerned find it agreeable ? Consider a declining firm, where a senior worker is entitled to collect two years of severance pay. Suppose that another firm were prepared to hire that worker. His seniority rights could be transferred to the new firm, subject to payment by the old firm of an appropriate premium ${ }^{15}$. This is a particular aspect of a broader issue, namely the accountancy of seniority rights. Whereas most fringe benefits are covered by contributions which are paid out on a flow basis, other benefits, like severance pay, never appear in the books of a firm, and are not covered by specific reserves ${ }^{16}$. Is this practice logical? The problem seems worth studying.

\section{Conclusion}

The central problem discussed in this lecture is that of reconciling efficient risksharing with decentralized incentives for efficient use of labour inputs, in private ownerships market economies with incomplete insurance markets.

14 See Drèze and Modigliani [1979].

15 This provision appears in the definition of contractual equilibria by Drèze and Greenberg [1977].

16 I understand that severance pay is covered by specific contributions in Italy. 
In Western Europe, the current recession illustrates dramatically the significance of this problem, and the limitations of the institutions which have emerged to cope with it.

Our theoretical understanding of the problem has been enhanced by important recent contributions, like those surveyed here, but it is still far from complete. The theory of risk-bearing has been applied more systematically to business decisions about physical or financial investment than to decisions about human resources; yet the potential usefulness of the theory seems to be even greater in the latter area.

It was suggested above that multiperiod general equilibrium would be an important step towards better understanding of the problems raised by risk-bearing and human resources. I may perhaps add, by way of conclusion, that the range of issues discussed here is still very narrow and leaves out important dimensions, like investment in human capital, incentives for effort and other qualitative aspects of work, the interactions of decisions on physical capital and human resources, etc.

These broader issues provide additional motivation to develop more comprehensive theoretical modeis. 


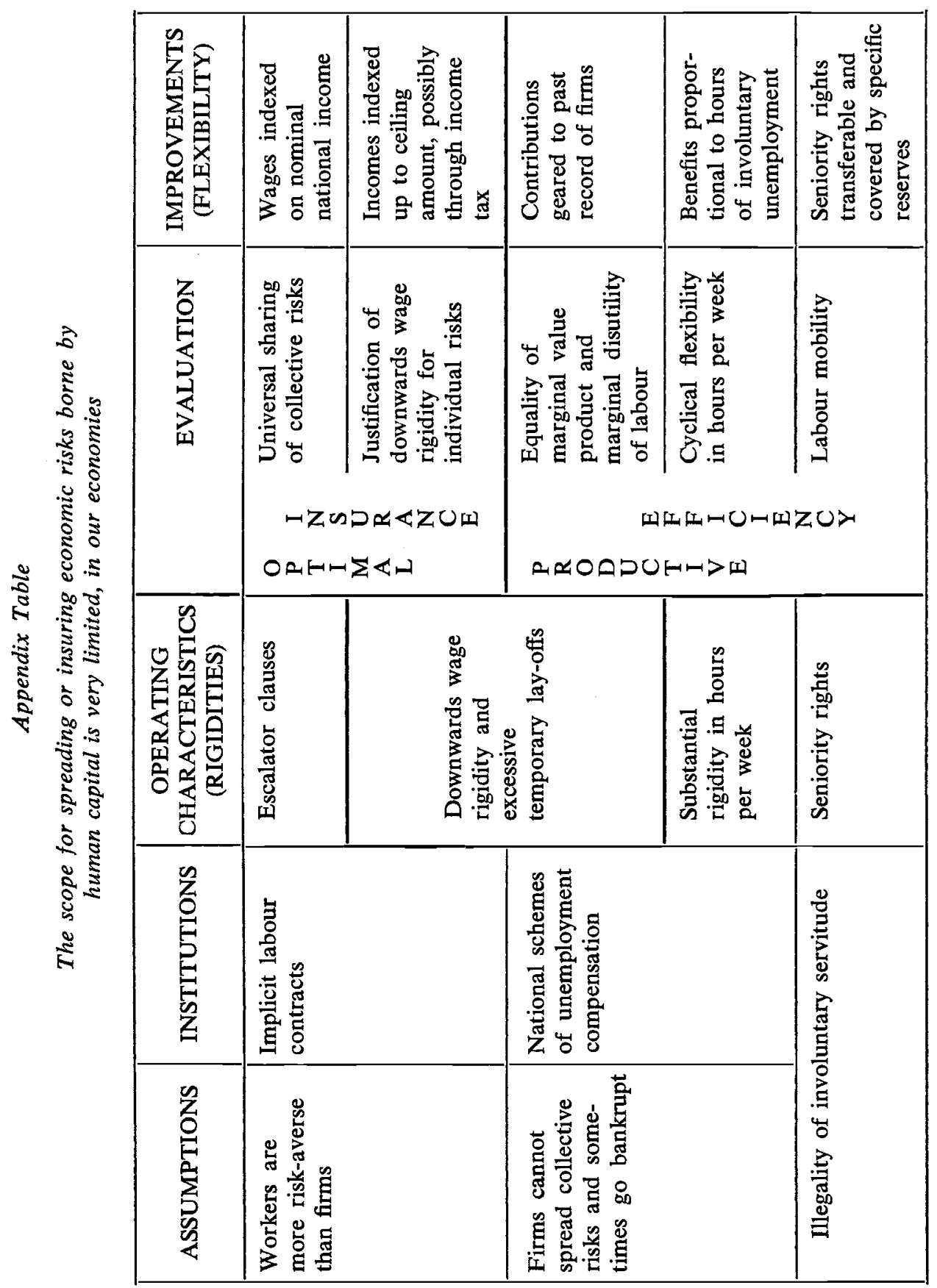




\section{REFERENCES}

ALLAIS, M. [1953] : “L'extension des théories de l'équilibre économique général et du rendement social au cas du risque", Econometrica, 21, 269-290.

ARROW, K. J. [1965] : Aspects of the Theory of Risk Bearing, Helsinki, Yrjö Jahnsson Foundation.

ARROW, K. J. [1970 a] ; Essays in the Theory of Risk Bearing, Amsterdam, North-Holland.

ARROW, K. J. [1970 b] : "On optimal insurance policies", Appendix to Essay 8 in Arrow [1970 a], 212-219.

ARROW, K. J. [1978] : “ Risk allocation and information : Some recent theoretical developments ", Geneva Papers on Risk and Insurance, 8, 5-19.

AZARIADIS, C. [1975] : “Implicit contracts and underemployment equilibria ", Journal of Political Economy, 83, 1183-1202.

AZARIADIS, C. [1977] : "Gordon on unemployment theory", Journal of Monetary Economics, 3, 253-255.

AZARIADIS, C. [1978] : "Escalator clauses and the allocation of cyclical risks", Journal of Economic Theory, 18, 119-155.

BAILY, M. N. [1974] : “Wages and employment under uncertain demand”, Review of Economic Studies, 41, 37-50.

BAILY, M. N. [1977] : “On the theory of layoffs and unemployment", Econometrica, 45, 1043-1063.

BARRO, R. J. [1977] : “Long-term contracting, sticky prices and monetary policy ", Journal of Monetary Economics, 3, 305-316.

BECKER, G. [1964] : Human Capital: A Theoretical and Empirical Analysis with Special Reference to Education, New York, Columbia University Press.

BORCH, K. [1960] : “The safety loading of reinsurance premiums”, Skandinavisk Aktuarietidskrift, $163-184$.

BORCH, K. [1977] : “The monster in Loch Ness", Chap. 16 in New Developments in the Applications of Bayesian Methods, A. Aykaç and C. Brumat, eds., Amsterdam, NorthHolland.

BORCH, K. [1979]: "The price of moral hazard", mimeo, Bergen, Norwegian School of Economics.

CAIN, G. G. [1976]: “The challenge of segmented labor market theories to orthodox theory: A survey ", Journal of Economic Theory, 14, 1215-1257. 
de KERCHOVE, A. M. [1976] : "Fluctuations de la demande, capacité de production et rémunération du facteur travail", mimeo, Institut des Sciences Economiques, Louvain.

DREZE, J. H. [1960] : “Le paradoxe de l'information”, Economie Appliquée, 13, 71-80.

DREZE, J. H. [1971] : “Market allocation under uncertainty”, European Economic Review, $2,135-165$.

DREZE, J.H. [1975] : “Existence of an exchange equilibrium under price rigidities", International Economic Review, 16, 301-320.

DREZE, J.H. [1976 a] : "Some theory of labor management and participation", Econometrica, 44, 1125-1139.

DREZE, J. H. [1976 b] : “Decision-making under uncertainty: The lessons from economic analysis, with reference to financial markets", mimeo, Genève, Institut International d'Etudes Bancaires et Monétaires.

DREZE, J. H., and JASKOLD GABSZEWICZ, J. [1967] : "Demand fluctuations, capacity utilization and prices", Operations Research Verfahren, 3, 119-141.

DREZE, J. H., and GREENBERG, J. [1977] : "Hedonic coalitions : Optimality and stability ", CORE Discussion Paper 7735, forthcoming in Econometrica.

DREZE, J. H., and HAGEN, K. P. [1978] : "Choice of product quality : Equilibrium and efficiency ", Econometrica, 46, 495-513.

DREZE, J. H., and MODIGLIANI, F. [1979]: “The trade-off between real wages and employment in an open economy", mimeo, Louvain-la-Neuve.

FELDSTEIN, M. [1974] : "Unemployment compensation, adverse incentives and distributional anomalies", National Tax Journal, 37, 231-244.

FELDSTEIN, M. [1976] : “Temporary layoffs in the theory of unemployment", Journal of Political Economy, 84, 937-952.

FISCHER, S. [1977] : “Long-term contracting, sticky prices and monetary policy, a comment ", Journal of Monetary Economics, 3, 317-323.

FRIEDMAN, M. [1953] : “La théorie de l'incertitude et la distribution des revenus selon leur grandeur", Econométrie, Paris, CNRS, 65-79.

FRIEDMAN, M., and KUZNETS, S. [1945]: Income from Independent Professional Practice, New York, National Bureau of Economic Research.

GORDON, D. F. [1974] : “A neo-classical theory of Keynesian unemployment”, Economic Inquiry, 12, 431-459.

GORDON, R. J. [1976] : "Aspects of the theory of involuntary unemployment", in The Phillips Curve and Labor Markets, K. Brunner and A. M. Meltzer, eds., Amsterdam, North-Holland. 
GORDON, R. J. [1977] : “Aspects of unemployment theory : Reply to Azariadis", Journal of Monetary Economics, 3, 257-260.

GROSSMAN, H. I. [1977] : “Risk shifting and reliability in labor markets”, Scandinavian Journal of Economics, 79, 187-209.

GROSSMAN, H. I. [1978 a] : “ Risk shifting, layoffs, and seniority", Journal of Monetary Economics, 4, 661-686.

GROSSMANN, H. I. [1978 b] : “Risk shifting, the dole and layoffs ”, Working Paper 78-21, Brown University, Providence.

HIRSHLEIFER, J. [1971] : "The private and social value of information and the reward to inventive activity", American Economic Review, 61, 561-574.

HOLMSTRÖM, B. [1979] : “Equilibrium long-term labour contracts”, mimeo, Helsinki, Svenska Handelshögskolan.

MALINVAUD, E. [1972] : "The allocation of individual risks in large markets", Journal of Economic Theory, 4, 312-328.

MEADE, J. [1972]: “The theory of labor-managed firms and of profit sharing", Economic Journal, 402-428.

OI, W. [1962] : “Labour as a quasi-fixed factor ”, Journal of Political Economy, 70, 538-555.

POLEMARCHAKIS, H. M., and WEISS, L. [1978] : “Fixed wages, layoffs, unemployment compensation, and welfare ", American Economic Review, 68, 909-917.

PRATT, J.W. [1964] : "Risk aversion in the small and in the large", Econometrica, 32, $127-136$.

SHESHINSKI, E., and DREZE, J. H. [1976] : “Demand fluctuations, capacity utilization, and costs ", American Economic Review, 66, 731-742.

STEINHERR, A. [1978]: “A new proposal for wage indexation", Bulletin de lIRES, 49, $1-16$.

STIGLITZ, J. [1974] : “Incentives and risks in sharecropping”, Review of Economic Studies, 41, 219-255.

TISDELL, C. A. [1968] : The Theory of Price Uncertainty, Production and Profit, Princeton, Princeton University Press. 